\title{
Adsorption Characterization of Strontium on PAN/Zeolite Composite Adsorbent
}

\author{
Sabriye Yusan ${ }^{1}$, Sema Erenturk ${ }^{2}$ \\ ${ }^{1}$ Institute of Nuclear Sciences, Ege University, Izmir, Turkey \\ ${ }^{2}$ Energy Institute, Ayazaga Campus, Istanbul Technical University, Istanbul, Turkey \\ E-mail: sabriye.doyurum@ege.edu.tr,erenturk@itu.edu.tr \\ Received February 1, 2011; revised March 10, 2011; accepted March 16, 2011
}

\begin{abstract}
This work reports the adsorption of strontium from aqueous solutions onto PAN/zeolite composite. The strontium adsorption on the composite adsorbent was studied as a function of initial strontium concentration, $\mathrm{pH}$ of the solution, contact time and temperature. Adsorption isotherms like Langmuir, Freundlich, Dubinin-Radushkevich (D-R) and Temkin were used to analyze the equilibrium data at the different concentrations. Adsorption process well fitted to Temkin isotherm model. Thermodynamic parameters such as the changes in enthalpy, entropy and Gibbs' free energy were determined, showing adsorption to be an exothermic and spontaneous process.
\end{abstract}

Keywords: Composite Adsorbents, Strontium, Sorption Behavior, Adsorption Isotherms, Thermodynamic Parameters

\section{Introduction}

Radioactive strontium occurs in the environment as ${ }^{89} \mathrm{Sr}$ and ${ }^{90} \mathrm{Sr}$ with half-lives of 51 days and 29 years respectively and it is not produced only as a waste fission product from nuclear power plants, also produced in the reprocessing of nuclear fuels [1]. Sr-90 as a main species is a soft $\beta$-emitter of $0.5460 \mathrm{MeV}$ energy. The most of ${ }^{90} \mathrm{Sr}$ existing in the environment can form to deposition alone with rain or other precipitation. Radiostrontium undergoes decay while emitting $\beta$-radiation and forms to ${ }^{90} \mathrm{Y}$ with a half-life of $64 \mathrm{~h}$, which is very strong $\beta$-emitter. Strontium-90 is relatively mobile and can move down with percolating water to underlying layers of soil and into groundwater. Strontium preferentially adheres to soil particles, and the amount in sandy soil is typically about 15 times higher than in interstitial water, concentration ratios are typically higher in clay [2].

Chemically, strontium resembles calcium, it is taken up via the gastrointestinal tract and collects in the body becoming part of the bone marrow tissue and damaging blood-producing cells. It is easily incorporated into bone and continues to irradiate localized tissues with the eventual development of bone sarcoma and leukemia. So, ${ }^{90} \mathrm{Sr}$ is considered as one of the most hazardous element in fission products. Furthermore, the high content of $\mathrm{Sr}$ as a heat-generator is unfavorable for vitrifying high level liquid waste (HLLW). Therefore, from the viewpoint of safety, eliminating $\mathrm{Sr}$ from the radionuclides is quite necessary prior to the final disposal of HLLW $[1,3]$.

Separation of strontium is particularly important in the determination of the radioactive isotopes of strontium ${ }^{89,90} \mathrm{Sr}$ in natural samples. Isotope ${ }^{89,90} \mathrm{Sr}$ are pure $\beta$-emitters and cannot be determinate without separating strontium from all natural and artificial radioactive isotopes present as well as from the elements contained in large quantities of natural samples such as potassium, sodium, calcium and iron [4].

The composite ion exchangers have been used in several studies to treatment of low and medium level liquid radioactive wastes [5-12], to investigate of sorption behavior of I to $\mathrm{V}$ group elements ( $\mathrm{Fr}, \mathrm{Ra}, \mathrm{Pb}, \mathrm{Bi}, \mathrm{Eu}, \mathrm{Zr}$, $\mathrm{Hf}, \mathrm{Th}, \mathrm{Nb}, \mathrm{Pa}, \mathrm{U})$ [13], to purification of ${ }^{223} \mathrm{Fr}$ from its decay products [14], to removal of some basic dyes [15], and $\mathrm{Na}$ from irradiated samples [16] and to mineralization of biological materials in neutron activation analysis [17].

PAN (polyacrylonitrile) is one of the most favorable binding materials for any inorganic materials, due to its physicochemical properties such as excellent pelletizing 
property, strong adhesive force with inorganic materials, good solubility for organic solvents and chemical stability [18]. Polyacrylonitrile is an inexpensive raw material and effectively immobilize to ion exchange materials into useful forms, such as spherical beads. PAN beads are highly porous and can accommodate very high loadings of ion exchange material (5 - 95\%wt) iFnto the PAN matrix. These highly porous PAN beads exhibit a number of advantages over other granular sorbents, namely; significantly improve kinetics and sorbent capacity due to increase availability of the sorbent material, easy modification of physico-chemical properties (hydrophilicity, porosity, mechanical strength), and simplified production [19].

To remove $\mathrm{Sr}$ ions selectively from low and medium level liquid radioactive wastes, organic/inorganic composite ion exchangers have been widely used [20-28].

In this study, PAN/zeolite composite adsorbent was prepared and studied adsorption of strontium from aqueous solution as a function of the initial strontium concentration, $\mathrm{pH}$, shaking time and temperature. The sorption data were interpreted using Langmuir, Freundlich, Dubinin-Radushkevich (D-R) and Temkin equation. Various thermodynamic parameters, including the mean free energy of sorption, were also determined.

\section{Experimental}

\subsection{Materials and Methods}

The zeolite (clinoptilolite) which is originated from Manisa-Gordes/Turkey was obtained from Pamukkale University, Turkey. The clinoptilolite was ground and wet sieved to a particle size of -200 mesh. Polyacrylonitrile (PAN) fiber was obtained from the Industry of Acrylic Chemistry (AKSA), Istanbul, Turkey.

The composite adsorbent was prepared from inorganic adsorbent, a natural zeolite clinoptilolite, as an active component and polyacrylonitrile (PAN) as a binding polymer. The composite beads were prepared in a flask with reflux as a reactor. Very fine colloidal particles of the clinoptilolite $(-200$ mesh) were stirred with the solution of PAN which was solved in $11.86 \mathrm{~g}$ of n-dimethylformamide (DMF) at $70^{\circ} \mathrm{C}$ for 1 hour to form homogeneous solution. The mass ratio of the PAN to clinoptilolite was adjusted at 1:1 [29]. The mixture was fed into the nozzle to obtain the spherical composite beads. Ultra pure distilled water (Millipore) was used as a gelatin agent. The composite beads were washed repeatedly by ultra pure distilled water to remove the solvent and then dried at $60^{\circ} \mathrm{C}$. The obtained spherical composite beads were sieved and fractionated according to the particle size. The dried composite adsorbent was stored in wide mouth plastic bottle for further use. It was assumed that the composite beads have homogeneous distribution of the inorganic particles in their matrix structure.

Arsenazo III and $\mathrm{SrCO}_{3}$ were obtained from Merck Co. All chemicals reagents used in the present study were of analytical reagent grade. The stock solution of strontium was prepared by dissolving an accurately weighed amount of strontium (II) carbonate $\left(\mathrm{SrCO}_{3}\right)$ in distilled water to achieve a concentration of $500 \mu \mathrm{g} / \mathrm{mL}$, and subsequently diluted to the required concentrations. The buffer solutions ( $\mathrm{pH}: 4,7$ and 9) to calibrate the $\mathrm{pH}$-meter model 8521 from Hanna Instruments were purchased from Merck. In all experiments, ultra pure distilled water was used for analytical purposes.

\subsection{Adsorption Experiments}

Adsorption studies were carried out by batch technique to obtain the equilibrium data. The experiments were carried out by agitating $10 \mathrm{~mL}$ of a solution containing different concentrations of $\mathrm{Sr}(\mathrm{II})$ in a thermostated water bath with $0.03 \mathrm{~g}$ of PAN/zeolite for various contact time. Batch adsorption experiments were carried in a (GFL1083 model) with a constant shaking rate. Filter-separating of solid phase from liquid was followed by centrifuging at $300 \mathrm{rpm}$ for $10 \mathrm{~min}$. The strontium was determined spectrophotometrically using Arsenazo III method as complexing agent at $640 \mathrm{~nm}$ against reagent blank, employing Shimadzu UV-VIS 260 Spectrophotometer [30]. In order to calculate the strontium concentration, the sorption of solution was compared with a working curve that was a plot of absorbance versus standard concentration of strontium. The amount of adsorbed strontium was estimated from the difference between the initial and final concentrations of strontium (II) by means of UV-VIS spectrophotometer (Model Shimadzu UV-VIS 260). All experiments were carried out at $298 \mathrm{~K}$ and in duplicate. $\pm 5 \%$ was the limit of experimental error of each duplicates, any experiment resulted in higher than this limit was repeated.

The percentage sorption of strontium from aqueous solution was computed as follows:

$$
\% \text { Adsorption }=\left[\left(C_{i}-C_{e}\right) / C_{e}\right] \times 100
$$

where $C_{i}$ : concentration of the initial solution $(\mu \mathrm{g} / \mathrm{mL})$, $C_{e}$ : concentration of the solution in equilibratio $(\mu \mathrm{g} / \mathrm{mL})$.

\subsection{Adsorption Isotherm}

Adsorption isotherms were studied by mixing a known amount of PAN/zeolite ( $0.03 \mathrm{~g}$ ) with various initial $\mathrm{Sr}$ (II) solution concentrations ranging from 25 to $175 \mu \mathrm{g} / \mathrm{mL}$ at $298 \pm 2 \mathrm{~K}$ and at $\mathrm{pH} 5$. The adsorption isotherms were obtained by analyzing solutions in contact with compo- 
site adsorbent before and after equilibrium and plotted in terms of the equivalent fraction of strontium in the composite phase against the equivalent fraction in the solution phase. The experimental data obtained in the present work was tested with the Langmuir, Freundlich, Dubinin-Radushkevich (D-R) and Temkin isotherm equations. Linear regression is frequently used to determine the best-fitting isotherm, and the applicability of isotherm equations is compared by judging the correlation coefficients.

\subsection{Thermodynamic Parameters}

Evaluation of thermodynamic parameters was made to assess the spontaneity of the sorption process. The influence of temperature variation was examined on the sorption of $\mathrm{Sr}(\mathrm{II})$ of fixed concentration $150 \mu \mathrm{g} / \mathrm{mL}$ onto PAN/zeolite composite using $20 \mathrm{~min}$ of equilibration time and temperature from $293 \mathrm{~K}$ to $333 \mathrm{~K}$. The thermo- dynamic parameters viz: Gibbs free energy change $\left(\Delta G^{\circ}\right)$, heat of sorption $\left(\Delta H^{\circ}\right)$ and entropy change $\left(\Delta S^{\circ}\right)$ for sorption of $\mathrm{Sr}(\mathrm{II})$ on PAN/zeolite composite were calculated for the system.

\section{Results and Discussion}

\subsection{Adsorption Experiments}

The effects of various parameters such as initial strotium concentration, $\mathrm{pH}$, contact time and temperature were investigated.

\subsubsection{Effect of Initial Concentration}

Sorption of $\mathrm{Sr}$ ions over the surface of the composite adsorbent was studied at the different concentrations (25 - $175 \mu \mathrm{g} / \mathrm{mL}$ ) of strontium ions at $25^{\circ} \mathrm{C}$. Figure 1 shows the adsorption yields for $\mathrm{Sr}$ ions on the composite adsorbent as a function of the initial strontium concentration. As shown in Figure 1, an initial rise of sorption attained an apparent saturation in $50 \mu \mathrm{g} / \mathrm{mL}$ of strontium concentration and percentage of adsorption increased with

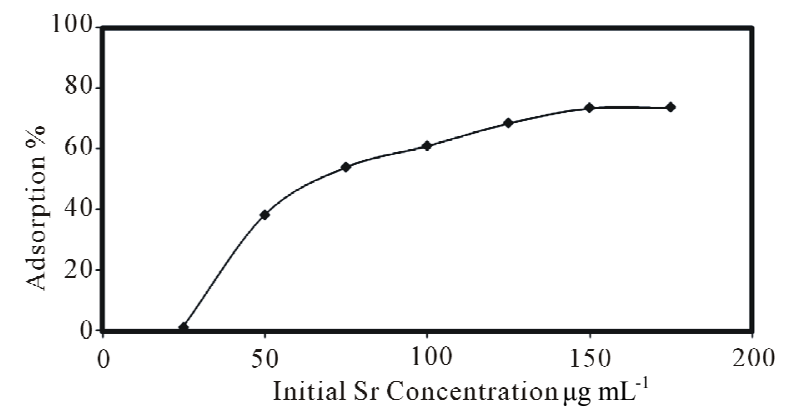

Figure 1. Effect of initial strontium concentration on the adsorption. increasing of strontium concentration. The percentage adsorption remained almost constant for strontium solution concentrations of $150-175 \mu \mathrm{g} / \mathrm{mL}$.

\subsubsection{Effect of $\mathbf{p H}$}

The $\mathrm{pH}$ of solution has been identified as one of the most important parameters affecting metal ion sorption. The effect of $\mathrm{pH}$ on the adsorption capacity of PAN/zeolite was investigated using solution of $150 \mu \mathrm{g} / \mathrm{L} \mathrm{Sr}$ (II) for a $\mathrm{pH}$ range of $2.0-8.0$ at $25^{\circ} \mathrm{C}$ for $120 \mathrm{~min}$. The $\mathrm{pH}$ of the solution was adjusted with $1 \mathrm{M} \mathrm{NaOH}$ and $1 \mathrm{M} \mathrm{HNO}_{3}$. After the sorption equilibrium, the supernatant solutions were filtered and the concentrations of strontium were determined spectrophotometer. The adsorption percentage of strontium on the composite adsorbent was calculated.

Figure 2 shows the effect of $\mathrm{pH}$, ranging from $\mathrm{pH} 2$ to $\mathrm{pH} 8$ on the removal of $\mathrm{Sr}$ by composite adsorbent. As seen from Figure 2, the highest adsorption levels for composite between $\mathrm{pH} 5 \pm 0.1$ and $6 \pm 0.1$ which indicate that a high affinity for strontium ions is predominant in this region. Therefore, $\mathrm{pH} 5 \pm 0.1$ was selected for further experiments with $84.6 \%$ adsorption yield.

According to strontium(II), hydrolysis constantsthe distribution of strontium species in demineralized water at the $\mathrm{pH}$ range from 1 to 11 can be present in the form of $\mathrm{Sr}^{2+}$ and a very negligible $\mathrm{Sr}(\mathrm{OH})^{+}$which increases in concentration above 10 and becomes the predominant specie above $\mathrm{pH} 13$. Therefore, at the $\mathrm{pH}$ range of $2-8$, strontium (II) has been found to be in the form of $\mathrm{Sr}^{2+}$ [31]. When $\mathrm{pH}$ is low ( $\mathrm{pH} 2$ ), the adsorbent almost has no more affinity to $\mathrm{Sr}(\mathrm{II})$ ions. Thus, the strong acidity results in replacing the adsorbed $\mathrm{Sr}(\mathrm{II})$ ions by the $\mathrm{H}^{+}$, which will decrease the adsorption capacity of $\mathrm{Sr}$ (II) ions. When $\mathrm{pH}$ values increase beyond $6.1 \pm 0.1$, precipitation starts due to the formation of complexes in aqueous solution and then the adsorption decreases [21,32].

\subsubsection{Effect of Contact Time}

In order to compare the adsorption ability of composite adsorbent, the effect of contact time on the adsorption of

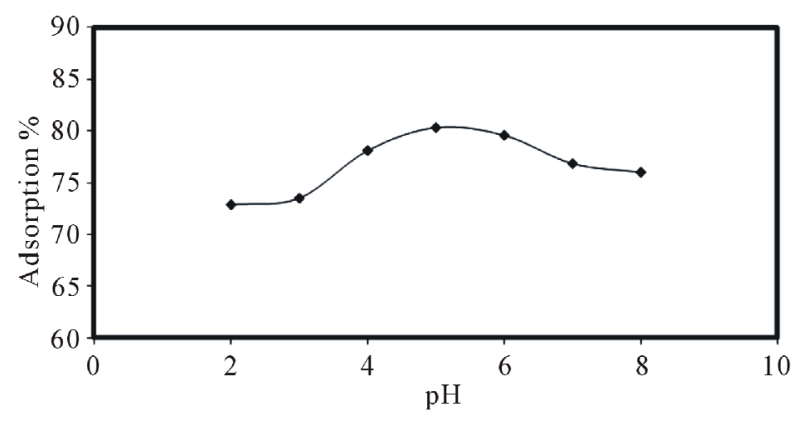

Figure 2. Effect of pH on the strontium adsorption. 
Sr(II) was investigated. Figure 3 shows the variation of percentage adsorption with shaking time. As demonstraed in Figure 3, the adsorption yield of $\mathrm{Sr}$ (II) onto composite adsorbent slightly increased with an increasing the contact time. These results show that the sorption process is rapid and equilibrium is reached almost instantaneously after mixing; no significant change occurs up to $240 \mathrm{~min}$. Therefore, $20 \mathrm{~min}$ reaction time was selected and used for all further studies. The instantaneous uptake of strontium by PAN/zeolite composite may be due to adsorption and/or exchange of the metal ions with some ions on the surface of the adsorbent.

\subsubsection{Effect of Temperature}

Temperature has a pronounced effect on sorption. So as to investigate the effect of temperature, the sorption of $\mathrm{Sr}$ (II) ions onto composite adsorbent was studied in the temperature range of 293 - $333 \mathrm{~K}$ under optimized conditions. Figure 4 illustrates the effect of temperature for adsorption of $\mathrm{Sr}(\mathrm{II})$ ions on the composite adsorbent. It is shown that the adsorption of $\mathrm{Sr}(\mathrm{II})$ on PAN/zeolite composite decreased as the solution temperature increased. This can be explained by the exothermic spontaneity of the adsorption process and by the weakening of bonds between $\mathrm{Sr}$ (II) and active sites of adsorbents at high temperatures.

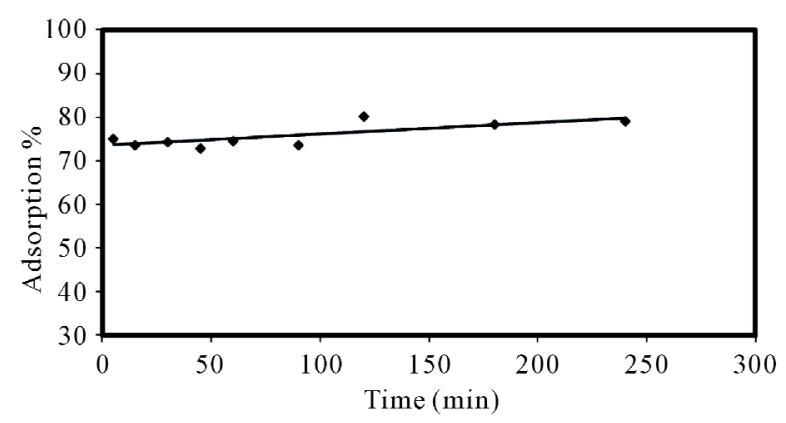

Figure 3. Variation of percentage sorption of strontium as a function of time.

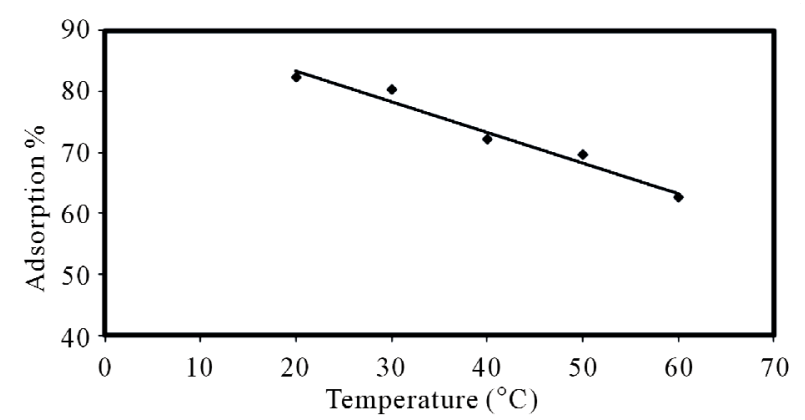

Figure 4. Effect of temperature on the strontium adsorption.

\subsection{Adsorption Isotherms}

Equilibrium data, commonly known as adsorption isotherms, are basic requirements for the design of adsorption systems. The distribution of metal ions between the liquid phase and the adsorbent is a measure of the position of equilibrium in the adsorption process and can generally be expressed by one or more of a series of isotherm models. In order to choose the best isotherm model to represent $\mathrm{Sr}(\mathrm{II})-\mathrm{PAN} /$ zeolite adsorption system, a set of equilibrium data has been tested on the Langmuir, Freundlich, D-R and Temkin isotherm models, respectively. The model equations are shown below (Equations 2-5):

$$
\begin{aligned}
& C_{e} / q_{e}=C_{e} / Q^{\circ}+1 / b Q^{\circ} \\
& \log q_{e}=\log K_{f}+1 / n \log C_{e} \\
& \ln C_{a d s}=\ln X_{m}-\beta \varepsilon^{2} \\
& q_{e}=B_{1} \ln K_{T}+B_{1} \ln C_{e}
\end{aligned}
$$

where $q_{e}$ is the adsorption capacity in equilibrium $(\mathrm{mg} / \mathrm{g}), C_{e}$ is the sorbate equilibrium concentration $(\mathrm{mg} / \mathrm{L}), \mathrm{b}(\mathrm{L} / \mathrm{mg})$ is the Langmuir constant associated to energy of adsorption and $Q^{\circ}$ denotes the theoretical monolayer adsorption capacity $(\mathrm{mg} / \mathrm{g}) . \quad K_{f}$ is the Freundlich constant $(\mathrm{mg} / \mathrm{g})$ while $1 / \mathrm{n}$ represents dimensionless heterogeneity factor. $C_{a d s}$ is the amount of sorbate sorbed by the composite $(\mathrm{mol} / \mathrm{g}), X_{m}$ is the maximum sorption capacity of sorbent $(\mathrm{mol} / \mathrm{g})$ under investigation, $\beta$ is a constant $\left(\mathrm{kJ}^{2} / \mathrm{mol}^{2}\right)$ related to energy and $\varepsilon$ is polany potential which is mathematically equal to $R T \ln \left(1+1 / C_{e}\right), \mathrm{R}$ is the universal gas constant in $\mathrm{kJ} / \mathrm{molK}, \mathrm{T}$ is absolute temperature in Kelvin and $C_{e}$ is the equilibrium concentration of $\mathrm{Sr}$ (II) in solution $(\mathrm{mol} / \mathrm{L})$ and $\beta\left(\mathrm{mol}^{2} / \mathrm{kJ}^{2}\right)$ indicates the activation energy, $\mathrm{E}(\mathrm{kJ} / \mathrm{mol})$ of adsorption per molecule of sorbate when it is transferred to the surface of the solid from infinity in the solution, where $E=1 / \sqrt{-2 \beta}$

Prior to equilibrium data plotting, all model equations were linearized accordingly [33].

The Temkin isotherm equation assumes that the heat of adsorption of all the molecules in layer decreases linearly with coverage due to adsorbent-adsorbate interactions, and that the adsorption is characterized by a uniform distribution of the bonding energies, up to some maximum binding energy [34]. The Temkin isotherm equation is given in Equation (5) above. $B_{1}$ is the Temkin constant related to heat of adsorption $(\mathrm{kJ} / \mathrm{mol}) . \mathrm{K}_{\mathrm{T}}$ is the equilibrium binding constant $(\mathrm{L} / \mathrm{mol})$ corresponding to the maximum binding energy. A plot of $q_{e}$ vs. $\ln C_{e}$ at studied temperature is given also in Figure $\mathbf{5}$.

The values of the constants for Langmuir, Freundlich, $\mathrm{D}-\mathrm{R}$ and Temkin isotherm models at $303 \mathrm{~K}$ for the remov- 
al of $\mathrm{Sr}(\mathrm{II})$ onto PAN/zeolite are presented in Table 1. The $\mathrm{R}^{2}$ value range obtained for the Temkin model is high when compared to those of the Langmuir, Freundlich and D-R models. Therefore the Temkin model is most suitable and that applicability follows the order; Temkin $>$ D-R $>$ Freundlich $>$ Langmuir adsorption models. This is a sign of a strong interaction between strontium ions and the adsorbents surface. The Temkin model shows a strong conformation to experimental data judging on satisfactorily values of the obtained linear regression coefficient, $\mathrm{R}^{2}$ (Table 1) $[33,35,36]$.

\subsection{Adsorption Thermodynamics}

The thermodynamic parameters viz: Gibbs free energy change $\left(\Delta G^{\circ}\right)$, heat of sorption $\left(\Delta H^{\circ}\right)$ and entropy change $\left(\Delta S^{\circ}\right)$ for sorption of $\operatorname{Sr}($ II) on PAN/zeolite composite system. These parameters were calculated from following equations:

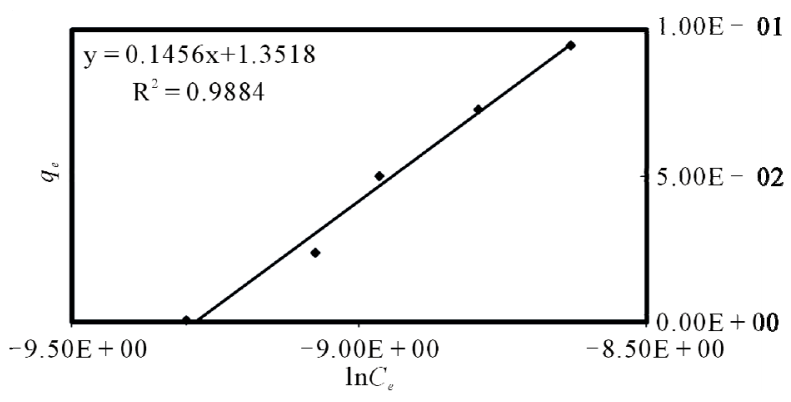

Figure 5. Temkin plot for the adsorption of $\operatorname{Sr}($ II) by PAN/zeolite: pH: 5; adsorbent dosage, $150 \mu \mathrm{g} / \mathrm{L}$; contact time, 20 min.

Table 1. Adsorption isotherm constants for the adsorption of Sr(II) onto PAN/zeolite (at $293 \pm 2 \mathrm{~K}$, pH 5).

\begin{tabular}{|c|c|c|}
\hline Model & Linearized equuation & $\begin{array}{l}\text { Parameters values for the } \\
\text { adsorption of } \mathrm{Sr}(\mathrm{II}) \text { on } \\
\text { PAN/zeolite }\end{array}$ \\
\hline Freundlich & $\log q_{e}=\log K_{f}+1 / n \log C_{e}$ & $\begin{array}{l}K_{f}=7.31 \times 10^{-13} \mathrm{mg} / \mathrm{g} \\
1 / n=7.6642 \\
R^{2}=0.7729\end{array}$ \\
\hline Temkin & $q_{e}=B_{1} \ln K_{T}+B_{1} \ln C_{e}$ & $\begin{array}{l}K_{T}=0.03991 L / \mathrm{mg} \\
B_{1}=3.5384 \\
R^{2}=0.9884\end{array}$ \\
\hline D-R & $\ln C_{a d s}=\ln X_{m}-\beta \varepsilon^{2}$ & $\begin{array}{l}\beta=6.04 \times 10^{-7}(\mathrm{~mol} / \mathrm{J}) \\
X_{m}=6.4695 \mathrm{mmol} / \mathrm{g} \\
E=0.91 \mathrm{~kJ} / \mathrm{mol} \\
R^{2}=0.8407\end{array}$ \\
\hline Langmuri & $C_{e} / q_{e}=C_{e} / Q^{\circ}+1 / b Q^{\circ}$ & $\begin{array}{l}Q^{\circ}=0.011 \mathrm{mg} / \mathrm{g} \\
b=0.00237 \\
R^{2}=0.4838\end{array}$ \\
\hline
\end{tabular}

$$
\Delta G^{\circ}=-R T \ln K_{d}
$$

where, $\mathrm{R}$ is the universal gas constant $(8.314 \mathrm{~J} / \mathrm{molK}), \mathrm{T}$ is temperature $(K)$ and $K_{d}\left(q_{e} C_{e}^{-1}\right)$ is the distribution coefficient [37,38]. The enthalpy $\left(\Delta H^{\circ}\right)$ and entropy $\left(\Delta S^{\circ}\right)$ parameters were estimated from the following Equation:

$$
\ln K_{d}=\Delta S^{\circ} / R-\Delta H^{\circ} / R T
$$

According to Equation (7), the values of $\Delta H^{\circ}$ and $\Delta S^{\circ}$ can be calculated from the slope and intercept of the plot of $\ln K_{d}$ vs $1 / T$ yields, respectively (Figure 6). Results are shown in Table 2.

The negative $\Delta H^{\circ}$ indicates the exothermic nature of the adsorption process and the positive value of $\Delta S^{\circ}$ suggests the increase in randomness at the solid/solution interface during the adsorption process. This occurs as a result of redistribution of energy between the adsorbate and the adsorbent [35]. The negative value $\Delta G^{\circ}$ indicates the degree of spontaneity of the process and higher negative value reflects a more energetically favorable sorption. The negative value of Gibbs free energy for $\mathrm{Sr}(\mathrm{II})$ adsorption on PAN/zeolite indicated the feasibility of the process and spontaneous nature of the adsorption. The degree of spontaneity of the process also increased with increasing temperature [39].

\section{Conclusions}

The present study focuses on adsorption of $\mathrm{Sr}$ (II) from aqueous solutions using the PAN/zeolite composite as a low cost sorbent. The adsorption characteristic has been examined with the variations in the parameters of concentration of $\mathrm{Sr}(\mathrm{II}), \mathrm{pH}$, contact time and temperature.

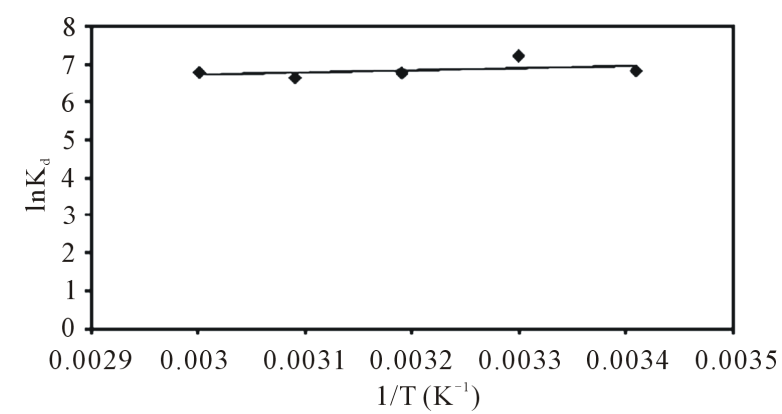

Figure 6. A plot against $\ln K_{d}$ to $1 / T$ for removal of $\operatorname{Sr}(\mathrm{II})$ from PAN/zeolite composite.

Table 2. Thermodynamic parameters for the adsorption of Sr(II) on PAN/zeolite composite.

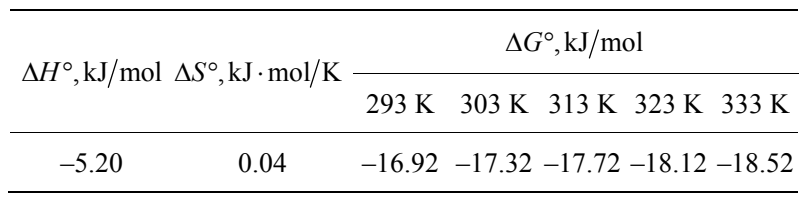


The $\mathrm{pH}$ experiments showed that the governing factors affecting the adsorption characteristics of adsorbent. Sorption is relatively high at $\mathrm{pH}$ 5. This phenomenon can be explain by competition of the $\mathrm{H}^{+}$ions with strontium ions at low $\mathrm{pH}$ values and precipitation of hydroxyl species onto the adsorbents $(\mathrm{pH} 6-8)$ at higher $\mathrm{pH}$.

The experimental results were analyzed by using the Langmuir, Freundlich, D-R and Temkin equations. The Temkin model appears to be the best fitting model for $\mathrm{Sr}$ (II) sorption on the adsorbent due to its high regression coefficient, $\mathrm{R}^{2}$ (0.9884). Also thermodynamic results support this suggestion. Thermodynamic parameters revealed that the adsorption process is exothermic and spontaneous with a increased randomness in nature.

The results provide information for the implementation of permeable reactive barrier technology to control the transport of radioactive $\mathrm{Sr}(\mathrm{II})$ and its species in natural surface and groundwater.

\section{References}

[1] D. Chakraborty, S. Maji, A. Bandyopadhyay and S. Basu, "Biosorption of Cesium-137 and Strontium-90 by Mucilaginous Seeds of Ocimum Basilicum," Short Communication. Bioresource Technology. Vol. 98, No.15, 2007, pp. 2949-2952. doi:10.1016/j.biortech.2006.09.035

[2] S. Chegrouche, A. Mellah and M. Barkat, "Removal of Strontium from Aqueous Solutions by Adsorption onto Activated Carbon: Kinetic and Thermodynamic Studies," Desalination, Vol. 235, No. 1-3, 2009, pp. 306-318. doi:10.1016/j.desal.2008.01.018

[3] A. Y. Zhang, Y. Z. Wei and M. Kumagai, "Synthesis of a Novel Macroporous Silica-Based Polymeric MaterialContaining 4, 4', (5')-Di(Tert-Butylcyclohexano)-18-Crown-6 Functional Group and Its Adsorption Mechanism for Strontium," Reactive and Functional Polymers, Vol. 61, No. 2, 2004, pp. 191-202.

doi:10.1016/j.reactfunctpolym.2004.05.004

[4] Z. Grahek, N. Zecevic and S. Lulic, "Possibility of Rapid Determination of Low-Level ${ }^{90} \mathrm{Sr}$ Activity by Combination of Extraction Chromatography Separation and Cherenkov Counting," Analytica Chimica Acta, Vol. 399, No. 15, 1999, pp. 237-247. doi:10.1016/S0003-2670(99)00469-9

[5] F. Sebesta, A. Motl and J. John, "Composite Ion Exchangers and Their Possible Use in Treatment of Low/Intermediate Level Liquid Radioactive Wastes," Proceedings of International. Conference. on Nuclear Waste Management and Environmental Remediation, Prague, Vol. 3, 5-11 Semptember 1993, pp.871.

[6] F. Sebesta and J. John, "An Overview of the Development, Testing and Application of Composite Absorbers," Los Alamos National Laboratory, New Mexico, Report No: LA-12875-MS, 1995, pp. 30.

[7] J. Narbutt, A. Bilewicz and B. Bartos, "Composite Ion Exchangers: Prospective Nuclear Applications," Journal of Radioanalytical and Nuclear Chemistry, Vol. 183, No. 1, 1994, pp. 27-32. doi:10.1007/BF02043113

[8] A. Mardan, R. Ajaz, A. Mehmood, S. M. Raza and A. Ghaffar, "Preparation of Silica Potassium Cobalt HexAcyanoferrate Composite Ion Exchanger and Its Uptake Behaviour for Cesium," Separation and Purification Technology, Vol. 16, No. 2, 1999, pp. 147-158. doi:10.1016/S1383-5866(98)00121-X

[9] Y. Onodera, H. Mimura, T. Iwasaki, H. Hayashi, T. Ebina and M. Chatterjee, "A New Granular Composite with high Selectivity for Cesium Ion Prepared from PhosphoMolyndic Acid Hydrate and Inorganic Porous Material," Separation Science and Technology, Vol. 34, No. 12, 1999, pp. 2347-2354.

[10] P. Rajec, J. Orechovska, I Novak, "NIFSIL: A New Composite Sorbent for Cesium," Journal of Radioanalytical and Nuclear Chemistry, Vol. 245, No. 2, 2000, pp. 317-321. doi:10.1023/A:1006758304650

[11] A. Mardan and R. Ajaz, "A New Method for Preparation of Silica Potassium Cobalt Hexacyanoferrate Composite ion Exchanger form Silica Sol," Journal of Radioanalytical and Nuclear Chemistry, Vol. 251, No. 3, 2002, pp. 359-361. doi:10.1023/A:1014857519804

[12] T. J. Tranter, R. S. Herbst, T. A. Todd, A. L. Olson and H. B. Eldredge, "Evaluation of Ammonium Molybdophosphate-Polyacrylonitrile (AMP-PAN) As a Cesium Selective Sorbent for the Removal of ${ }^{137} \mathrm{Cs}$ from Acidic Nuclear Waste Solutions," Advances in Environmental Research., Vol. 6, No. 2, 2002, pp. 107-121. doi:10.1016/S1093-0191(00)00073-3

[13] Z. Szeglowski, O. Constantinescu and M. Hussonnois, "Sorption Behaviour of I to V Group Elements on a Nickel Hexacyanoferrate (II) Composite Ion Exchanger," Radiochima Acta, Vol. 64, 1994, pp.127-130.

[14] Z. Szeglowski, O. Constantinescu, M. Hussonnois, A. Abdul-Hadi and G. J. Arddisson, "Continous Purification of ${ }^{223} \mathrm{Fr}$ from Its Decay Products on a Nickel Hexacyanoferrate (II) Composite Ion Exchanger," Radiochima Acta, Vol. 64, 1994, pp. 57-59.

[15] M. H. Abo-Shosha, N. A. Ibrahim and A. El-Halwagi, "Color Removal of Some Basic Dyes Using Cellulose/Glycidyl Methacrylate/Acrylic Acid Cation-Exchange Composite," American Dyestuff Reporter, Vol. 82, No. 2, 1993, pp. 41-47.

[16] A. Mardan and J. O. Liljenzin, "Dynamic Capacity and Mass Transfer for Removal of $\mathrm{Na}^{+}$by a Composite Hydrate Antimony Pentoxide-Organic Ion Exchanger," Journal of Radioanalytical and Nuclear Chemistry, Vol. 133, No. 2, 1989, pp.343-348. doi:10.1007/BF02060507

[17] H. Polkowska-Motrenko, W. Zmijewska, B. Bartos, A. Bilewicz and J. Narbutt, "Composite Ion Exchanger for Removal of Sodium-24 from Mineralizates of Biological Materials in Neutron Activation Analysis, Journal of Radioanalytical and Nuclear Chemistry, Vol. 164, No. 2, 1992, pp. 115-122. doi:10.1007/BF02167971

[18] J.-K. Moon, C.-H. Jung, E.-H. Lee, H.-T. Kim and Y.-G. Shul, "Preparation of PAN-Zeolite 4A Composite Ion 
Exchanger and Its Uptake Behavior for Sr and Cs Ions in Acid Solution," Korean Journal of Chemical Engineering, Vol. 19, No. 5, 2002, pp. 838-842. doi:10.1007/BF02706978

[19] N. R. Mann, T. A. Todd, T. J. Tranter and F. Sebesta, "Development of Novel Composite Sorbents for the Removal of Actinides from Environmental and Analytical Solutions," Journal of Radioanalytical and Nuclear Chemistry, Vol. 254, No. 1, 2002, pp. 41-45. doi:10.1023/A:1020829228253

[20] J.-K. Moon, K.-W. Kim, C.-H. Jung, Y.-G. Shul and E.-H. Lee, "Preparation of Organic-Inorganic Composite Adsorbent Beads for Removal of Radionuclides and Heavy metal Ions," Journal of Radioanalytical and Nuclear Chemistry, Vol. 246, No. 2, 2000, pp. 299-307. doi:10.1023/A:1006714322455

[21] N. Sahai, S. A. Caroll, S. Roberts and P. A. O’Day, "X-ray Adsorption Spectroscopy of Strontium(II) Coordination: II. Sorption and Precipitation at Kaolinite, Amorphous Silica and Goethite Surfaces," Journal of Colloid and Interface Science, Vol. 222, No. 2, 2000, pp. 198-212. doi:10.1006/jcis. 1999.6562

[22] O. N. Karasyova, L. I. Ivanova, L. Z. Lakshtanov and L. Lövgren, "Strontium Sorption on Hematite at Elevated Temperatures," Journal of Colloid and Interface Science, Vol. 220, No. 2, 1999, pp. 419-428. doi:10.1006/jcis.1999.6474

[23] S. M. Hasany and M. H. Chandhary, "Adsorption Studies of Strontium on Manganese Dioxide from Aqueous Solutions," Internnational Journal. of Applied. Radiation Isotopes, Vol. 32, No. 12, 1981, pp. 899-904. doi:10.1016/0020-708X(81)90076-4

[24] T. Cole, G. Bidoglio, M. Soupioni, M. O'Gorman and N. Gibson, "Diffusion Mechanisms of Multiple Strontium Species in Clay," Geochimica et Cosmochimica Acta, Vol. 64, No. 3, 2000, pp. 385-396. doi:10.1016/S0016-7037(99)00324-5

[25] R. A. Shawabkeh, D. A. Rockstraw and R. K. Bhada, "Copper and Strontium Adsorption by a Novel Carbon Material Manufactured from Pecan Shells," Carbon, Vol. 40, No. 5, 2002, pp. 781-786. doi:10.1016/S0008-6223(01)00198-1

[26] R. Qadeer, J. Hanif, M. Saleem and M. Afzal, "Selective Adsorption of Strontium on Activated Charcoal from Electrolytic Aqueous Solutions," Collection of Czechoslovak Chemical Communications, Vol. 57, No. 10, 1992, pp. 2065-2072. doi:10.1007/BF02706978

[27] F. Sebesta, J. John, A. Motl and J. Watson, "Development of PAN Based Adsorbers for Treating Waste Problems at U.S. DOE Facilities," In: S. Slate, F. Feizollahi and J. Creer., Eds., Proceedings of the ICEM-5th International Conference on Radioactive Waste Management and Environmental Remediation, Berlin, 3-7 september 1995, ASME, NewYork, Vol. 1, pp. 361.

[28] J.-K. Moon, C.-H. Jung, E.-H. Lee, H.-T. Kim and Y.-G.
Shul, "Preparation of PAN-Zeolite 4A Composite Ion Exchanger and Its Uptake Behavior for Sr and Cs Ions in Acid Solution," Korean Journal of Chemical Engineering, Vol. 19, No. 5, 2002, pp. 838-842. doi:10.1007/BF02706978

[29] S. Akyil and M. Eral, "Preparation of Composite Adsorbents and Their Characteristics," Journal of Radioanalytical and Nuclear Chemistry, Vol. 266, No. 1, 2005, pp. 89-93. doi:10.1007/s10967-005-0874-7

[30] H. Onishi, "Photometric Determination of Traces of Metals Fourth Edition Part IIB: Individual Metals, Magnesium to Zirconium," A Wiley-Interscience Publication, New York, 1989, pp. 411-418.

[31] R. Yavari, Y. D. Huang and A. Mostofizadeh, "Sorption of Strontium Ions from Aqueous Solutions by Oxidized Multiwall Carbon Nanotubes," Journal of Radioanalytical and Nuclear Chemistry, Vol. 285, No. 3, 2010, pp. 703-710. doi:10.1007/s10967-010-0600-y

[32] M. Wang, L. Xu, J. Peng, M. Zhai, J. Li and G. Wei, "Adsorption and Desorption of $\mathrm{Sr}(\mathrm{II})$ Ions in the Gels Based on Polysaccharide Derivates," Journal of Hazardous Materials, Vol. 171, No. 1-3, 2009, pp. 820-826. doi:10.1016/j.jhazmat.2009.06.071

[33] A. T. Mohd Din and B. H. Hameed, "Adsorption of Methyl Violet Dye on Acid Modified Activated Carbon: Isotherms and Thermodynamics," Journal of Applied Sciences in Environmental Sanitation, Vol. 5, No. 2, 2010, pp. 161-170.

[34] M. J. Tempkin and V. Pyzhev, "Kinetics of Ammonia Synthesis on Promoted Iron Catalysts, "Acta Physicochim U. R. S.S, Vol. 12, 1940, pp. 217-222.

[35] N. K. Amin, "Removal of Direct Blue-106 Dye from Aqueous Solution Using New Activated Carbons Developed from Pomegranate Peel: Adsorption Equilibrium and Kinetics," Journal of Hazardous Materials, Vol. 165, No. 1-3, 2009, pp. 52-62. doi:10.1016/j.jhazmat.2008.06.077

[36] M. Yurtsever and I. A. Sengil, "Biosorption of Pb(II) Ions by Modified Quebracho Tannin Resin," Journal of $\mathrm{Ha}$ zardous Materials, Vol. 163, No. 1, 2009, pp. 58-64. doi:10.1016/j.jhazmat.2008.06.077

[37] E. Tutem, R. Apak and C. F. Unal, "Adsorptive Removal of Chlorophenols from Water by Bituminous Shale," Water Research, Vol. 32, No. 8, 1998, pp. 2315-2324. doi:10.1016/S0043-1354(97)00476-4

[38] S. S. Gupta and K. G. Bhattacharyya, "Adsorption of $\mathrm{Ni}(\mathrm{II})$ on Clays," Journal of Colloid and Interface Science, Vol. 295, No. 1, 2006, pp. 21-32. doi:10.1016/j.jcis.2005.07.073

[39] A. L. Ahmad, C. Y. Chan, S. R. Abd Shukor and M. D. Mashitah, "Adsorption Kinetics and Thermodynamics of $\beta$-Carotene on Silica-Based Adsorbent," Chemical Engineering Journal, Vol 148, No. 2-3, 2009, pp. 378-384.. doi:10.1016/j.cej.2008.09.011 